\title{
School of Economics
}

\section{Entrepreneurship, risk perception and firm performance}

\author{
Martijn Boermans \\ Daan Willebrands
}




\section{Tjalling C. Koopmans Research Institute Utrecht University School of Economics Utrecht University}

Kriekenpitplein 21-22

3584 EC Utrecht

The Netherlands

telephone $\quad+31302539800$

fax +31302537373

website www.uu.nl/use/research

The Tjalling C. Koopmans Institute is the research institute and research school of Utrecht University School of Economics. It was founded in 2003, and named after Professor Tjalling C. Koopmans, Dutch-born Nobel Prize laureate in economics of 1975.

In the discussion papers series the Koopmans Institute publishes results of ongoing research for early dissemination of research results, and to enhance discussion with colleagues.

Please send any comments and suggestions on the Koopmans institute, or this series to L.M.vanDort@uu.nl

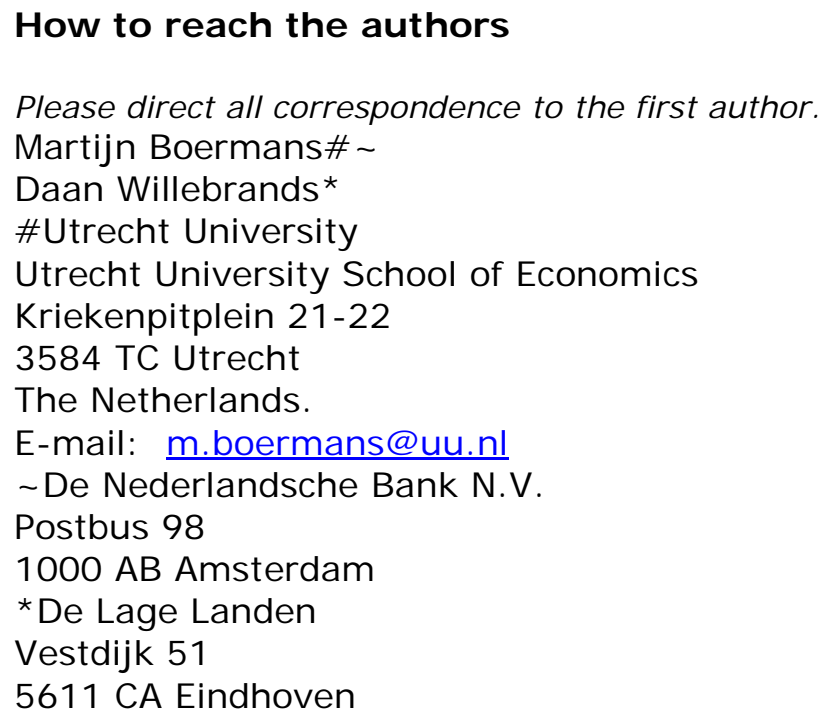




\title{
Entrepreneurship, risk perception and firm performance
}

\author{
Martijn Boermans ${ }^{a b}$ \\ Daan Willebrands ${ }^{c}$ \\ aUtrecht School of Economics \\ Utrecht University \\ ${ }^{\mathrm{b}}$ De Nederlandsche Bank N.V. \\ ${ }^{\mathrm{c}}$ De Lage Landen \\ February 2017
}

\begin{abstract}
Risk attitudes of entrepreneurs are well-established drivers of business performance. Most empirical studies in this field only take into account risk propensity, leaving out the complementary concept of risk perception. Using data on 611 entrepreneurs from Tanzania, we show that risk perception is positively associated with business performance. In addition, we classify the entrepreneurs in four different groups based on their risk profile. The results show that the worst performing entrepreneurs are those with low risk perception and high risk propensity.
\end{abstract}

Keywords: risk attitude; risk perception; risk propensity; entrepreneurship; business performance; Africa

JEL classification: D22, D81, L26, 012. 


\section{I ntroduction}

In the entrepreneurship literature risk propensity and risk perception are often viewed as important drivers of entrepreneurial success. In defining entrepreneurship, scholars often refer to the bearing of or exposure to risk, separating entrepreneurs from employees and managers (e.g., Begley and Boyd, 1987). In this study, we focus on the impact of risk related variables on the business outcomes of small enterprises in Tanzania. In particular, we are interested in how the perception of risk is associated with firm performance. This channel is theoretically relevant as proper identification of risk can increase successful entrepreneurship in developing areas.

We contribute to this theoretical literature by including both risk propensity and risk perception in the analysis of firm performance. Most previous studies only focus on risk propensity, which is shown to be an important driver of entrepreneurship. We thereby provide a more complete approach to estimating the impact of two key dimensions of risk on firm performance. In addition, we contribute to the rather incomplete literature on risk perception by looking at firm performance. Most of the risk perception literature has so far only analysed the impact on decision making.

Our study fits well into a growing entrepreneurship literature on developing countries. We use unique survey data from entrepreneurs who borrow at a microfinance institution in Tanzania. We estimate the effect of risk propensity on firm performance using OLS regressions. In addition, our empirical approach circumvents the methodological issue of multicollinearity between risk propensity and risk propensity by defining four different groups of entrepreneurs in terms of their risk profile. This makes it possible to analyse the effects of both factors at the same time. We find that risk perception has a significant impact on firm performance among small 
business owners in Tanzania. A one standard deviation of higher risk perception is associated with $8 \%$ higher revenue. On the other hand, entrepreneurs who generally perceive risks as being low and who at the same time have a high propensity to take risks have a $28 \%$ to $40 \%$ lower revenue than other entrepreneurs. We argue that the results may be explained by the literature that suggests that low risk perception is associated with an incorrect assessment of risks. Taking a lot of risk in such cases could lead to sub-optimal decision-making and, hence, lower business performance.

This paper commences as follows. Section 2 places this empirical study in the entrepreneurship literature and connects it to research on risk perception and risk propensity. Section 3 motivates the context of this paper and provides details on the survey data. Section 4 presents our results and Section 5 concludes with a discussion.

\section{Related literature}

In this section, we elucidate how studies on risk perception and risk propensity have important ramifications for the entrepreneurship literature. Let us start with the broad literature on the effects of risk propensity and risk perception on firm performance. The entrepreneurial orientation (EO) literature emphasises both concepts through risk taking characteristics of entrepreneurs. The EO literature focuses on five key dimensions that facilitate the entrepreneurial process and explain firm performance autonomy, innovativeness, proactiveness, competitive aggressiveness, and risk taking (e.g., Lumpkin and Dess, 1996; Wiklund and Shepard, 2003). Often the definition of entrepreneurship itself refers to a risk taking element. Åstebro et al. (2014) define entrepreneurship by the perception of opportunities in the face of unknown distributions of risk. Here we focus on 
the risk taking elements from the EO literature. In their conceptual study on EO, Lumpkin and Dess (1996, p.144) stress that entrepreneurs are 'venturing into the unknown'. In this way, they emphasise that research on entrepreneurship needs to clarify how entrepreneurs deal with such situations by focusing on to what extent an entrepreneur 'ventures into the unknown'. The most closely related construct to this is risk propensity.

Most studies on the importance of risk related factors for firm performance focus on risk propensity or the tendency of an entrepreneur to take risk (Begley and Boyd, 1987; Lumpkin and Dess, 1996; Wiklund and Shepherd, 2003). Risk propensity can be understood as the entrepreneur's general likelihood of behaving more or less in a risky manner and how entrepreneurs evaluate the risk-return trade-off [see Sitkin and Pablo, (1992), p.12] or the affinity for or tolerance of calculated risk (Dana, 2002). Because risk taking and risk propensity are so closely linked, most empirical work focuses on the effect of risk propensity on entrepreneurial performance. A broad range of studies find that risk taking is one of the defining characteristics of the entrepreneur that affects business outcomes, however, the size and sign of the effect of risk taking on performance is ambiguous. In their meta-analysis covering 60 studies Zhao et al. (2010) do not find evidence of a significant impact of risk propensity on performance. In fact there is no consensus on the sign of the effect (see Rauch et al., 2009). One reason for this lack of consensus may be differences in definitions and measurement of risk propensity. Another could be the fact that the concept of risk taking is a more complex concept that requires a more elaborate approach as Sitkin and Pablo (1992) suggest.

A range of studies find negative effects of risk propensity on performance. Naldi et al. (2007) find that in family businesses a higher propensity to take risk decreases performance. Tang and Tang (2007) also 
find a negative effect of risk propensity on performance. Tang et al. (2010) also find a negative effect for small firms. They argue that this may be because of confounding factors that lead to a nonlinear relationship between risk propensity and performance. Lechner and Gudmundsson (2014) study the effect of risk propensity for small Icelandic firms and show that a high risk propensity decreases differentiation strategies and cost leadership methods thereby lowering firm performance. Thapa (2015) studies the role of risk propensity on microenterprise performance in Nepal and finds no effect.

In the EO literature, the perception of risk is an additional driver of risk taking [see Lumpkin and Dess, (1996), p.145; Sitkin and Pablo, (1992), p.12], yet receives relatively little empirical attention (e.g., Randerson et al., 2016). We argue that the mixed results in the EO literature regarding risk propensity may well be explained by the use of a narrow concept of risk taking. Both risk propensity and risk perception need to be accounted for when explaining firm performance. A number of studies suggest that the concept of risk taking is more complex and that in addition to risk propensity the perception of risk is important as well (e.g., Boermans and Willebrands, 2012; Cressy, 2006; Dana, 1995; Gibcus et al., 2009; Gundolf and Jaouen, 2005; Kraus et al., 2012; Sitkin and Pablo, 1992; Willebrands et al., 2012).

We define risk attitude as a broad description of the way the decision maker deals with risk, of which risk propensity and risk perception are two main aspect (Blais and Weber, 2006). The theoretical distinction between risk perception and risk propensity is based on the idea that individuals differ both in their tendency to take risks as well as in the way they see and interpret risks. According to Blais and Weber (2006), the prominence of affective reactions in perceptions of risk cause individual differences in risk 
perception. This in turn is based on differences in heuristics (e.g., Slovic et al., 2004). Risk perception therefore captures a different part of the risk attitude than risk propensity. Sitkin and Pablo (1992, p.12) define risk perception as "a decision maker's assessment of the risk inherent in a situation". It is broadly thought to impact business outcomes through underestimation or overestimation of risks. Indeed, it is how the entrepreneur perceives the opportunity rather than the opportunity itself that matters (Dana and Dana, 2005). Lower risk perception may be the result of entrepreneurs framing the business situation too positively (e.g., Norton and Moore, 2006; Palich and Bagby, 1995). Willebrands et al. (2012) argue that this could lead to a lack of risk mitigation. In turn, poor risk mitigation is thought to reduce performance (Murmann and Sardana, 2013).

Despite the recognised importance of entrepreneurs' risk perception in the literature, its effect on business outcomes has been little studied. Most empirical studies make use of experimental designs and only look at the impact of risk perception on a single, predefined decision (Forlani and Mullins, 2000; Norton and Moore, 2006). Sitkin and Weingart (1995), for example, show that higher risk perception leads to less risky decisionmaking by entrepreneurs, but do not analyse the effect on firm performance. The impact of risk perception may also be different in actual business situations as entrepreneurship involves a continuous process of decision-making. Palich and Bagby (1995) find that entrepreneurs have a tendency to evaluate business situations more positively than nonentrepreneurs because they focus more on the opportunities of the situation than on the weaknesses and threats. In this way, the differences in risk perception among entrepreneurs can have strong impact on business outcomes. Various studies in the entrepreneurship literature further highlight the importance of risk perception for entrepreneur's start-up 
choices (e.g., Arenius and Minniti, 2005; Forlani and Mullens, 2000; Simon et al., 2000). Hormiga and Bolivar-Cruz (2014) show that among immigrants in Spain, the perception of risk influences the decision to become an entrepreneur. Robinson and Marino (2013) argue that overconfidence can deteriorate firm performance. They show that risk perception is an important moderator for overconfidence, thus making an indirect positive contribution to entrepreneurial outcomes. In a closely related study to our work, Willebrands et al. (2012) find that higher risk perception is related to higher revenue among market salesmen in Nigeria.

\section{Context and data}

\subsection{Context of developing countries}

The analysis is based on data on 611 entrepreneurs from the harbour city of Dar es Salaam in Tanzania. Dar es Salaam is the largest city in the country with an estimated population of 4 million. Tanzania is considered a poor, developing country with an average income per capita of around $\$ 2,000$ (PPP) in 2010, also the year of our sample. In many ways, the region is comparable to other developing areas that are coping with infrastructural, health and poverty concerns.

A stratified sample based on different locations of the various offices of a large credit institution was obtained. The samples of entrepreneurs that we interviewed have their own business and are registered with a specific microfinance institution. Before the determination of the potential list of respondents, reference information such as age, gender and loan size was obtained. Using this information a stratified sample was determined to obtain a uniform spread in loan size. After completion of the interviews, there was no systematic difference between the sampled individuals and the individuals that were interviewed. 
The entrepreneurs were interviewed at the household. The household surveys were part of a large impact evaluation study and also included medical examination of the respondents (AIID, 2010). The interviews were conducted in Swahili by local residents especially trained for the program. The interviews were completed in two parts. The first part focused on the business and work environment of the entrepreneur. The interviews for this part took about one hour. The second part of the interviews covered health related aspects of the household and these responses were not used for this paper. Data was collected from March to May 2010.

\subsection{Operationalisation}

The survey contains a psychometric scale to elucidate risk perception and risk propensity by the entrepreneur, based on the design by Blais and Weber (2006) and applied in many other studies (e.g., Foster et al., 2009; Mishra et al., 2010). An advantage of this method is that the scales are easy to understand and do not require a high level of financial literacy. For six different risky actions, respondents were asked to indicate how risky they perceive the action to be on a seven-point Itemised rating scale ranging from (1) 'Not at all risky' to (7) 'Extremely risky'. These six items were then combined and averaged to measure risk perception. Subsequently, the respondents were asked to indicate for each of the six items how likely it would be for them to take the action, by which risk propensity could be measured. Appendix shows the six questions. ${ }^{1}$

Risk perception and risk propensity are two key dimensions of the entrepreneur's risk attitude. Most empirical studies on risk attitude use a single risk measure as input in the regression analysis. Including both risk

\footnotetext{
${ }^{1}$ Risk perception is not correlated to education, the age of the entrepreneur or other control variables.
} 
perception and risk propensity in the estimation may lead to insignificant results because of high correlation between the two measures $(r=0.6)$. When both explanatory variables are used at the same time, multicollinearity inflates the variance in the model, thus leading to lower tvalues and lower significance of the regression estimates. However, OLS estimates are still consistent, unbiased and efficient [Brooks, (2006), p.192]. In line with the proposed solutions to potentially obtaining low tvalues arising from multicollinearity for our risk variables in Brooks (2006) and Wooldrige (2006 p.104), we combine the two risk measures into a single variable. For this we define four groups based on their elicited risk attitude. This means that we group our risk variables together. By defining four groups of entrepreneurs it is possible to analyse the combined effect of risk perception and risk propensity. This way we capture the effects of the two risk measures in combination while allowing for a proper estimation.

In the regression analysis entrepreneurs are classified according to high and low risk perception and risk propensity. This leads to the following groups:

\section{1 low risk perception and low risk propensity;}

2 high risk perception and low risk propensity;

\section{3 low risk perception and high risk propensity;}

\section{4 high risk perception and high risk propensity.}

Figure 1 shows an overview of the four groups. 'Low' risk perception or propensity is defined as a score below or equal to the sample mean, and 'high' is defined as a score higher than the sample mean. 
Figure 1 Four types of risk attitudes

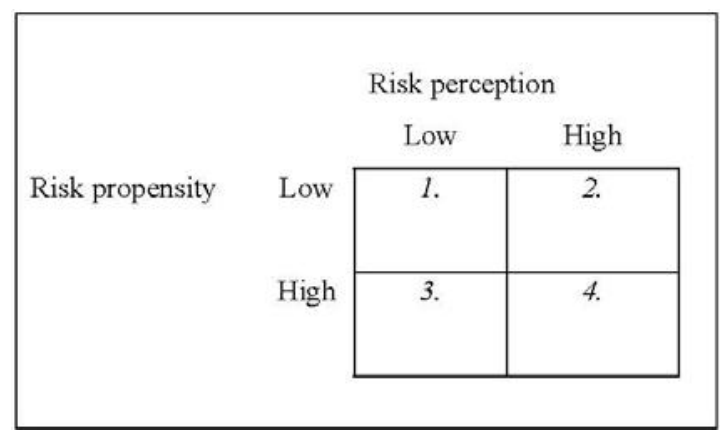

In developing countries, measuring firm productivity of small businesses is difficult because of lack of bookkeeping (Daniels, 2001). This study uses revenue to measure firm performance because is a relatively simple and reliable concept in this context. In addition, revenue is a good proxy of firm productivity (De Mel et al., 2009). The entrepreneurs were asked to indicate their sales in a high, average and low month. Next they had to indicate how many months had seen high, average, and low sales over the past 12 months. From this the total sales in the past 12 months were calculated. The differentiation between high and low sales makes it easier for the entrepreneur to estimate their sales and reduces the recall bias. The differentiation also corrects for seasonality.

The analysis includes a large set of standard control variables that is often used in small business literature in developing countries (e.g., Bigsten and Gebreeyesus, 2007; Masakure et al., 2008; Nichter and Goldmark, 2009). We correct the outcomes for entrepreneur characteristics - gender, age and education level - and for firm characteristics - firm age, number of employees, number of months the business was open over the past 12 months, and sector. The inclusion of a young firm dummy follows from the insight that business start-ups are on a different growth trajectory than long-established firms. In this process they may have to make initial investments. Other papers also use information on the firm age as potential 
determinant of small business performance, as young firms typically experience decreased performance (e.g., Boermans and Roelfsema, 2016; Kraus et al., 2012; Masakure et al., 2008). Given that the sample includes relatively small businesses that in various cases operate directly from the household, there is potentially large differentiation between the number of months that the business operates. The period of inactivity will depress firm sales, hence we include a variable that covers information about the number of months that the firm was open.

Table 1 shows that $65 \%$ of the entrepreneurs are female and 35\% are male. The average age is 38 years. Only $7 \%$ has enjoyed secondary education or higher, while the majority has completed primary school. The average annual revenue is 9.3 million TZS (around 5,700 USD at market exchange rate) and $18 \%$ of the businesses have existed for two year or less. More than $60 \%$ of businesses have no employees. The businesses are typically small (with no employees) and cover a wide range of activities such as tailoring and stationary shops.

On a seven-point Itemised rating scale, the average score of the risk perception measure is 4.4 , meaning that on average the entrepreneurs perceive the actions as between 'Moderately risky' and 'Risky'. The average risk propensity score is 3.3. These scores are comparable to those found in several other studies that use a similar scale (Blais and Weber, 2006; Foster et al., 2009; Mishra et al., 2010; Willebrands et al., 2012). 
Table 1 Sample descriptive statistics

\begin{tabular}{lccccc}
\hline & Mean & Median & St. dev. & Min. & Max \\
\hline Revenue (1,000 TZS) & 9,335 & 5,210 & 19,000 & 70 & 374,000 \\
Risk perception & 4.4 & 4.3 & 1.1 & 1 & 7 \\
Risk propensity & 3.3 & 3.5 & 1.0 & 1 & 7 \\
1. Low risk perception & $13 \%$ & & & & \\
2. High risk perception & $35 \%$ & & & & \\
3. Low risk perception & $35 \%$ & & & & \\
4. High risk perception & $17 \%$ & & & & \\
Male & $35 \%$ & & & & \\
Age & 38 & 36 & 8.6 & & \\
Secondary educ. or higher & $7 \%$ & & & & \\
Young firm (<=2 years) & $18 \%$ & & & & 12 \\
Number of employees & 0.7 & 0 & 1.4 & & \\
Months open & 11.5 & 12 & 1.4 & 1 & \\
Food & $29 \%$ & & & & \\
Tailoring & $6 \%$ & & & & \\
Clothing & $15 \%$ & & & & \\
Other trade & $27 \%$ & & & & \\
Other services & $23 \%$ & & & & \\
\hline
\end{tabular}

Note: Based on 611 observations.

\section{Empirical results}

Using OLS regressions, first the risk attitude items are used separately to estimate the effect on firm performance. Column 1 in Table 2 shows that risk perception is positively and significantly associated with revenue. An increase of risk perception by one standard deviation is associated with $13 \%$ higher revenue, ceteris paribus. The findings in column 2 show that risk propensity has a significant negative effect on revenue. Column 3 includes both risk perception and risk propensity in a single estimation. This results in insignificant coefficients for the risk attitude measures.

The main results in column 4 in Table 2 are based on the four risk attitude groups of entrepreneurs. The reference group (3) is characterised by low risk perception and high risk propensity. Column 4 shows that entrepreneurs with a low risk perception and low risk propensity (group 1) have $29 \%$ higher estimated revenue than the reference group. 
Entrepreneurs with a high risk perception and a low risk propensity (group 2) have $40 \%$ higher estimated revenue. Finally, group 4 has $28 \%$ higher estimated revenues. There is, however, no significant difference in the size of the effect between groups (1), (2), and (4) in Table $2(F=0.7 ; p=$ $0.50)$.

The findings show that the worst performing group is thus the reference group 3, entrepreneurs who generally see little risk, but are likely to take large risks. This suggests that performance is improved when entrepreneurs perceive risks and take them into account in making their decisions (group 2 and group 4), or when they are blind to risks but avoid taking them (group 1).

Regarding the control variables, most of our findings are generally in line with other studies in developing countries (e.g., Grimm et al., 2011; Masakure et al., 2008; Minniti and Naudé, 2010; Nichter and Goldmark, 2009; Sleuwaegen and Goedhuys, 2002; Willebrands et al., 2012). We show that women show weaker firm performance, possibly suggesting a disadvantaged position of women or better entrepreneurial performance by males (see Grimm et al., 2011; Minniti and Naudé, 2010; Nichter and Goldmark, 2009; Ramadani el al., 2015). In contrast to Bigsten and Gebreeyesus (2007), we find no significant effect of the age of the entrepreneur. The impact of education in our context also appears to be limited (Grimm et al., 2011; Sleuwaegen and Goedhuys, 2002). The age of the firm is a significant determinant of performance, as firms mature they perform better (Sleuwaegen and Goedhuys, 2002). The number of employees also enters significant, yet this only signals that the sales of our entrepreneurs are higher for those with more employees. Note that most firms in our context do not have other workers except the entrepreneur. We also find that business that are open more months perform better, however, 
this is also a result of our output approach. Finally, in terms of sectors we do not find much difference compared to the benchmark. The only result that stands out is the fact that the sales of tailors are much lower than of other entrepreneurs, in line with Sleuwaegen and Goedhuys (2002) and Willebrands et al. (2012). In sum, taking into account our control variables which overall have the expected signs, we find that risk perception and risk propensity are significant determinants of firm performance.

Table 2 Effects of risk perception and risk propensity on log revenue

\begin{tabular}{|c|c|c|c|c|c|c|c|c|}
\hline & Coeff. & S.E. & Coeff. & S.E. & Coeff. & S.E. & Coeff. & S.E. \\
\hline Risk perception & $0.13 * * *$ & $(0.04)$ & & & $0.08 *$ & $(0.05)$ & & \\
\hline Risk propensity & & & $-0.14 * * *$ & $(0.04)$ & -0.08 & $(0.05)$ & & \\
\hline $\begin{array}{l}\text { Low risk } \\
\text { perception, } \\
\text { low risk } \\
\text { propensity }\end{array}$ & & & & & & & $0.29 * *$ & $(0.12)$ \\
\hline $\begin{array}{l}\text { High risk } \\
\text { perception, } \\
\text { low risk } \\
\text { propensity }\end{array}$ & & & & & & & $0.40 * * *$ & $(0.10)$ \\
\hline $\begin{array}{l}\text { High risk } \\
\text { perception, } \\
\text { high risk } \\
\text { propensity }\end{array}$ & & & & & & & $0.28 * *$ & $(0.13)$ \\
\hline Male & $0.37 * * *$ & $(0.09)$ & $(0.09)$ & $0.36 * * *$ & $0.37 * * *$ & $(0.09)$ & $0.37 * * *$ & $(0.09)$ \\
\hline Age & 0.05 & $(0.04)$ & $(0.04)$ & 0.06 & 0.05 & $(0.04)$ & 0.05 & $(0.04)$ \\
\hline $\mathrm{Age}^{\wedge} 2$ & -0.00 & $(0.00)$ & $(0.00)$ & -0.00 & 0.00 & $(0.00)$ & 0.00 & $(0.00)$ \\
\hline $\begin{array}{l}\text { Secondary } \\
\text { education }\end{array}$ & 0.06 & $(0.10)$ & $(0.10)$ & 0.05 & 0.07 & $(0.10)$ & 0.06 & $(0.10)$ \\
\hline $\begin{array}{l}\text { Young firm } \\
(<=2 \\
\text { years) }\end{array}$ & $-0.32 * * *$ & $(0.11)$ & $-0.29 * * *$ & $(0.11)$ & $-0.31 * * *$ & $(0.11)$ & $-0.30 * * *$ & $(0.11)$ \\
\hline $\begin{array}{l}\text { Number of } \\
\text { employees }\end{array}$ & $0.18 * * *$ & $(0.05)$ & $0.18 * * *$ & $(0.05)$ & $0.18 * * *$ & $(0.05)$ & $0.18 * * *$ & $(0.05)$ \\
\hline Months open & $0.16 * * *$ & $(0.03)$ & $0.16 * * *$ & $(0.03)$ & $0.16 * * *$ & $(0.03)$ & $0.16 * * *$ & $(0.03)$ \\
\hline Food & -0.07 & $(0.12)$ & -0.06 & $(0.12)$ & -0.07 & $(0.12)$ & -0.09 & $(0.12)$ \\
\hline Tailoring & $-0.85 * * *$ & $(0.21)$ & $-0.84 * * *$ & $(0.21)$ & -0.84 & $(0.21)$ & $-0.85 * * *$ & $(0.22)$ \\
\hline Clothing & 0.00 & $(0.13)$ & -0.00 & $(0.13)$ & 0.00 & $(0.13)$ & -0.02 & $(0.13)$ \\
\hline $\begin{array}{l}\text { Other } \\
\text { trade }\end{array}$ & 0.10 & $(0.11)$ & 0.10 & $(0.12)$ & 0.10 & $(0.11)$ & 0.07 & $(0.11)$ \\
\hline Constant & $11.78 * * *$ & $(0.78)$ & $12.72 * * *$ & $(0.76)$ & $12.22 * * *$ & $(0.81)$ & $12.13^{* * *}$ & $(0.78)$ \\
\hline R-squared & 0.21 & & 0.21 & & 0.21 & & 0.22 & \\
\hline
\end{tabular}

Notes: Based on 611 observations. $* * *, * *$ and $*$ denote significance at the $1 \%, 5 \%$ and $10 \%$ level respectively. Standard errors are based on the Huber-White (sandwich) estimators. 


\section{Discussion}

A widely held view in the EO literature is that risk-taking behaviour is a key driver of firm performance. This study contributes to this literature on a conceptual level by focusing on the little studied area of risk perception in addition to the well-studied concept of risk propensity (see Zhao et al., 2010; Rauch et al., 2009). It is broadly accepted that risk perception can affect firm performance as under- or over-estimation of risks may lead to suboptimal business outcomes (Åstebro et al., 2014; Palich and Bagby, 1995) and insufficient use of risk mitigation measures (Murmann and Sardana, 2013; Willebrands et al., 2012). Broadening the concept of risk attitude beyond the concept of willingness to take risk could open the way to a more comprehensive view on the relationship between risk attitude and firm performance.

The empirical results of this study highlight the importance of both risk propensity and risk perception as determinant of business outcomes. Using data from small businesses in Tanzania it is shown that risk perception is a valuable concept in analysing firm performance. Entrepreneurs with higher perception of risk in general earn higher revenue. Previous literature on the risk perception shows that higher risk perception leads to less risky decision making (Sitkin and Weingart, 1995). Our results would thus suggest that the impact of this lower risk decision making improves revenue among entrepreneurs in Tanzania. This could be the result of better risk mitigation measures or due to underestimation of risk by entrepreneurs with a low perception of risks. Risk mitigation measures such as inventory management, product diversification, direct cash payments and insurance can support long term business development, especially in high risk environments (Boermans and Willebrands, 2012; Dercon, 2008). Future research should therefore analyse how risk perception impacts decision 
making and how that in turn impacts firm performance. Only then a clear view arises on the way risk perception matters.

The empirical results confirm the suggestion by the theoretical papers that risk attitude is more than risk propensity and risk perception is also a relevant dimension. We find that entrepreneurs who are willing to take a lot of risk but generally perceive few risks show the poorest performance. This may be due to a lack of compensation for higher risk taking combined with a lack of risk mitigation measures due to a low risk perception. This relationship should be analysed more directly by future research. In addition, our approach, while more comprehensive than only looking at risk propensity, is still rather simple compared to the more elaborate theory on risk attitude as defined by Sitkin and Pablo (1992). A more comprehensive assessment of risk attitude may therefore further improve the understanding of the impact of risk attitude on firm performance.

\section{Appendix}

For each of the items in Table Al, the respondent is asked to indicate how likely he/she is to take the action and how risky they perceive the action to be. Both are scored on a seven-point itemised rating scale.

Table A1 Risk perception and risk-taking items

\footnotetext{
1 Betting a day's income at a high-stake card game, such as poker

2 Investing $10 \%$ of your annual income in a new business venture

3 Betting a day's income on the outcome of a sporting event, such as soccer

4 Investing $10 \%$ of your annual income in shares

5 Investing $10 \%$ of your annual income in a wonder bank or other scheme that promises you a very high return on savings

6 Investing $10 \%$ of your annual income in a new farming technology

Note: The question items are the same as in Willebrands et al. (2012) and are based on Blais and Weber (2006).
} 


\section{References}

AIID (2010) Impact Evaluation of HIF-Supported Health Insurance Projects in Tanzania: Microcredit Clients, Baseline Report, Amsterdam Institute for International Development.

Arenius, P. and Minniti, M. (2005) 'Perceptual variables and nascent entrepreneurship', Small Business Economics, Vol. 24, No. 3, pp.233-247.

Åstebro, T., Herz, H., Nanda, R. and Weber, R. (2014) 'Seeking the roots of entrepreneurship: insights from behavioral economics', Journal of Economic Perspectives, Vol. 28, No. 3, pp.49-69.

Begley, T. and Boyd, D. (1987) 'A comparison of entrepreneurs and managers of small business firms', J ournal of Management, Vol. 13, No. 1, pp.99-108.

Bigsten, A. and Gebreeyesus, M. (2007) 'The small, the young, and the productive: determinants of manufacturing firm growth in Ethiopia', Economic Development and Cultural Change, Vol. 55, No. 4, pp.813-840.

Blais, A. and Weber, E. (2006) 'A domain-specific risk-taking (DOSPERT) scale for adult populations', Judgment and Decision Making, Vol. 1, No. 1, pp.3347.

Boermans, M. and Roelfsema, H. (2016) 'Small firm internationalization, innovation, and growth', International Economics and Economic Policy, Vol. 13, No. 2, pp. 283-296.

Boermans, M. and Willebrands, D. (2012) Financial Constraints, Risk Taking and Firm Performance: Recent Evidence from Microfinance Clients in Tanzania, DNB Working paper No. 358.

Brooks, C. (2006) Introductory Econometrics for Finance, 7th ed., Cambridge University Press, UK.

Cressy, R. (2006) 'Why do most firms die young?', Small Business Economics, Vol. 26, No. 2, pp.103-116.

Dana, L. (1995) 'Entrepreneurship in a remote sub-Arctic community', 
Entrepreneurship Theory and Practice, Vol. 20, No. 1, pp.57-72.

Dana, L.P. (2002) 'Sustainable development in the Maldives: the Dhivehi context of entrepreneurship', International J ournal of Entrepreneurship and Innovation Management, Vol. 2, No. 6, pp.557-565.

Dana, L.P. and Dana, T.E. (2005) 'Expanding the scope of methodologies used in entrepreneurship research', International J ournal of Entrepreneurship and Small Business, Vol. 2, No. 1, pp.79-88.

Daniels, L. (2001) 'Testing alternative measures of microenterprise profits and net worth', Journal of International Development, Vol. 13, No. 5, pp.599614.

De Mel, S., McKenzie, D. and Woodruff, C. (2009) 'Measuring microenterprise profits: must we ask how the sausage is made?', Journal of Development Economics, Vol. 88, No. 1, pp.19-31.

Dercon, S. (2008) 'Fate and fear: risk and its consequences in Africa', Journal of African Economies, Vol. 17, No. 2, pp.97- 127.

Forlani, D. and Mullins, J. (2000) 'Perceived risks and choices in entrepreneurs' new venture decisions', Journal of Business Venturing, Vol. 15, No. 4, pp.305-322.

Foster, J., Shenesey, J. and Goff, J. (2009) 'Why do narcissists take more risks? Testing the roles of perceived risks and benefits of risky behaviors', Personality and Individual Differences, Vol. 47, No. 8, pp.885-889.

Gibcus, P., Vermeulen, P. and De Jong, J. (2009) 'Strategic decision making in small firms: a taxonomy of small business owners', International J ournal of Entrepreneurship and Small Business, Vol. 7, No. 1, pp.74-91.

Grimm, M., Krüger, J. and Lay, J. (2011) 'Barriers to entry and returns to capital in informal activities: Evidence from Sub-Saharan Africa', Review of Income and Wealth, Vol. 57, No. s1, pp.S27-S53.

Gundolf, K. and Jaouen, A. (2005) 'Patterns and coordination of collective 
action in small and very small business: the case of a tourist village in the Pyrenees', International Journal of Entrepreneurship and Small Business, Vol. 2, No. 4, pp.392-403.

Hormiga, E. and Bolívar-Cruz, A. (2014) 'The relationship between the migration experience and risk perception: a factor in the decision to become an entrepreneur', International Entrepreneurship and Management Journal, Vol. 10, No. 2, pp.297-317.

Kraus, S., Rigtering, J., Hughes, M. and Hosman, V. (2012) 'Entrepreneurial orientation and the business performance of SMEs: a quantitative study from the Netherlands', Review of Managerial Science, Vol. 6, No. 2, pp.161182.

Lechner, C. and Gudmundsson, S.V. (2014) 'Entrepreneurial orientation, firm strategy and small firm performance', International Small Business Journal, Vol. 32, No. 1, pp.36-60.

Lumpkin, G. and Dess, G. (1996) 'Clarifying the entrepreneurial orientation construct and linking it to performance', Academy of Management Review, Vol. 21, No. 1, pp.135-172.

Masakure, O., Cranfield, J. and Henson, S. (2008) 'The financial performance of non-farm microenterprises in Ghana', World Development, Vol. 36, No. 12, pp. 2733-2762.

Minniti, M. and Naudé, W. (2010) 'What do we know about the patterns and determinants of female entrepreneurship across countries', European Journal of Development Research, Vol. 22, No. 3, pp.277-293.

Mishra, S., Lalumiere, M. and Williams, R. (2010) 'Gambling as a form of risktaking: individual differences in personality, risk-accepting attitudes, and behavioral preferences for risk', Personality and Individual Differences, Vol. 49, No. 6, pp.616-621.

Murmann, J. and Sardana, D. (2013) 'Successful entrepreneurs minimize risk', 
Australian J ournal of Management, Vol. 38, No. 1, pp.191-215.

Naldi, L., Nordqvist, M., Sjöberg, K. and Wiklund, J. (2007) ‘Entrepreneurial orientation, risk taking, and performance in family firms', Family Business Review, Vol. 20, No. 1, pp.33-47.

Nichter, S. and Goldmark, L. (2009) 'Small firm growth in developing countries', World Development, Vol. 37, No. 9, pp.1453-1464.

Norton, W. and Moore, W. (2006) 'The influence of entrepreneurial risk assessment on venture launch or growth decisions', Small Business Economics, Vol. 26, No. 3, pp.215-226.

Palich, L.E. and Bagby, D.R. (1995) 'Using cognitive theory to explain entrepreneurial risk-taking: challenging conventional wisdom', Journal of Business Venturing, Vol. 10, No. 6, pp.425-438.

Ramadani, V., Dana, L.P., Gërguri-Rashiti, S. and Abazi-Alili, H. (2015) 'The profile of female entrepreneurs in the Republic of Macedonia', Female Entrepreneurship in Transition Economies, pp.159-180, Palgrave Macmillan, UK.

Randerson, K., Degeorge, J.M. and Fayolle, A. (2016) 'Entrepreneurial opportunities: how do cognitive styles and logics of action fit in?', International Journal of Entrepreneurship and Small Business, Vol. 27, No. 1, pp.19-39.

Rauch, A., Wiklund, J., Lumpkin, G. and Frese, M. (2009) 'Entrepreneurial orientation and business performance: an assessment of past research and suggestions for the future',

Robinson, A.T. and Marino, L.D. (2013) 'Overconfidence and risk perceptions: do they really matter for venture creation decisions?', International Entrepreneurship and Management Journal, Vol. 11, No. 1, pp.149-168.

Simon, M., Houghton, S.M. and Aquino, K. (2000) 'Cognitive biases, risk perception, and venture formation: how individuals decide to start 
companies', Journal of Business Venturing, Vol. 15, No. 2, pp.113-134.

Sitkin, S. and Pablo, A. (1992) 'Reconceptualizing the determinants of risk behavior', The Academy Management Review, Vol. 17, No. 1, pp.9-38.

Sitkin, S. and Weingart, L. (1995) 'Determinants of risky decision-making behavior: a test of the mediating role of risk perceptions and propensity', The Academy of Management Journal, Vol. 38, No. 6, pp.1573-1592.

Sleuwaegen, L. and Goedhuys, M. (2002) 'Growth of firms in developing countries, evidence from Cote d'Ivoire', Journal of Development Economics, Vol. 68, No. 1, pp.117-135.

Slovic, P., Finucane, M.L., Peters, E. and MacGregor, D.G. (2004) 'Risk as analysis and risk as feelings: some thoughts about affect, reason, risk, and rationality', Risk Analysis, Vol. 24, No. 2, pp.311-322.

Tang, J. and Tang, Z. (2007) 'The relationship of achievement motivation and risk-taking propensity to new venture performance: a test of the moderating effect of entrepreneurial munificence', International Journal of Entrepreneurship and Small Business, Vol. 4, No. 4, pp.450-472.

Tang, Z., Kreiser, P.M., Marino, L. and Weaver, K.M. (2010) 'Exploring proactiveness as a moderator in the process of perceiving industrial munificence: a field study of SMEs in four countries', Journal of Small Business Management, Vol. 48, No. 2, pp.97-115.

Thapa, A. (2015) 'Determinants of microenterprise performance in Nepal', Small Business Economics, Vol. 45, No. 3, pp.581-594.

Wiklund, J. and Shepherd, D. (2003) 'Knowledge-based resources, entrepreneurial orientation, and the performance of small and mediumsized businesses', Strategic Management Journal, Vol. 24, No. 13, pp.13071314.

Willebrands, D., Lammers, J. and Hartog, J. (2012) 'A successful businessman is not a gambler: risk attitude and business performance among small 
enterprises in Nigeria', Journal of Economic Psychology, Vol. 33, No. 2, pp. 342-354.

Wooldrige, J. (2006) Introductory Econometrics: A Modern Approach, 3rd ed., Thomson South-Western, USA.

Zhao, H., Seibert, S. and Lumpkin, G. (2010) 'The relationship of personality to entrepreneurial intentions and performance: a meta-analytic review', Journal of Management, Vol. 36, No. 2, pp.381-404. 